\title{
Ecosystem Service Commodification: Lessons from California
}

\author{
Marissa Bongiovanni Schmitz and Erin Clover Kelly*
}

\begin{abstract}
In 2013 the state of California launched a cap-and-trade program with a groundbreaking protocol for improved forest management (IFM), providing a framework to monetize carbon sequestration in managed forests. Through in-depth interviews and document review, this research examines California's IFM program development as a case study in stakeholder-engaged ecosystem commodification. We consider how diverse, vested-interest actors contested rival program design options by using the familiar narratives of ecological modernization, green governmentality, and civic environmentalism. The results reveal the benefits and complexities of delegating methodological design to stakeholders who seek direct participation in the market, and highlight the challenges of balancing multiple program objectives, including environmental benefits, legitimacy and market reception, and landowner participation potential. This research provides a unique window into the complex process of forest-offset program design and offers broader lessons for ecosystem markets currently being designed and implemented globally.
\end{abstract}

In 2013 the state of California launched a cap-and-trade program with a pioneering protocol for improved forest management (IFM), providing a framework to monetize forests' potential as greenhouse gas (GHG) reduction sinks, through the production of forest carbon offsets. Programs monetizing forest offsets date to the 1990s, spanning voluntary schemes for carbon footprint reduction and regulatory programs, such as the emissions trading system of the 1992 United Nations Framework Convention on Climate Change. ${ }^{1}$ However, methodologies guiding forest-offset production are yet unstandardized. High variation in forestoffset program design reflects both technical and political challenges, including difficulty measuring and monetizing terrestrial carbon, as well as policy debates surrounding the use of forests as GHG sinks (Boyd et al. 2008). Amid this methodological experimentation and uncertainty, California's IFM protocol emerged with

* This material is based on work that is supported by the National Institute of Food and Agriculture, U.S. Department of Agriculture McIntire-Stennis program, accession number 231837. We wish to thank three anonymous reviewers, whose suggestions helped to improve this manuscript.

1. Preceding regulatory programs included the Activities Implemented Jointly (AIJ) and Clean Development Mechanism (CDM), which incentivized avoided deforestation and tree planting (afforestation/reforestation). See Boyd et al. (2008) and Thomas et al. (2010). 
original definitions of baseline, permanence, and natural forest management, crafted by the stakeholder participants of two successive workgroups. Because this occurred in a relatively transparent public process, we have the opportunity to assess California's IFM program development as a case study in stakeholder-engaged ecosystem commodification. We asked: How did workgroup participants negotiate key and consequential design features? What environmental governance discourses were brought to bear on specific design elements? And what does this reveal about stakeholders' ability to shape the design and functioning of payment for ecosystem service (PES) markets through access to program design?

We found that both state and nonstate actors played key roles in creating the IFM protocol, with the state setting the legal groundwork and convening workgroup participants who sought to create a workable market solution, while excluding stakeholders opposed to marketizing carbon. Stakeholders selected for IFM workgroup participation made policy decisions about who and what to incentivize, which frequently favored their own market entrance. This was evident through a comparison of separately produced IFM protocol iterations, formulated by workgroups of different stakeholder compositions. This analysis revealed that the original, land-trust-designed protocol included provisions favorable to conservation landowners, such as requisite placement of conservation easements on project lands. However, a second protocol, produced in collaboration with large commercial forest interests, significantly altered market access through removal of the conservation easement requirement and inclusion of even-aged management (or clear-cutting). Analysis further revealed that vestedinterest actors lobbied for particular design preferences using familiar forest-offset narratives. Here, we build on the findings of Bäckstrand and Lövbrand (2006), who articulated three discourses present in global forest-offset policy discussions: ecological modernization, green governmentality, and civic environmentalism (Bäckstrand and Lövbrand 2006). Our results show that these discourses drove debates over core methodological preferences, explaining much about how these novel goods are successfully brought to market.

This article begins by reviewing the complexities of delegating PES program design to vested-interest actors. Second, we explain the framework of Bäckstrand and Lövbrand (2006), highlighting the tensions and overlap between the dominant narratives informing forest-offset policy. Thereafter, a chronology of IFM protocol development details the evolving stakeholder debates over baseline, permanence, and natural forest management-criteria selected here because they shape program participation. This narrative is divided into two sections addressing successive workgroups' efforts (Figure 1): The first developed a protocol for California's voluntary offset market; the second significantly revised the original protocol for use in the eventual cap-and-trade market. ${ }^{2}$

2. Multiple iterations were released of each protocol, reflecting adjustments made by the Climate Action Reserve. However, this study is concerned with the broader differences between the protocols produced by each workgroup. 


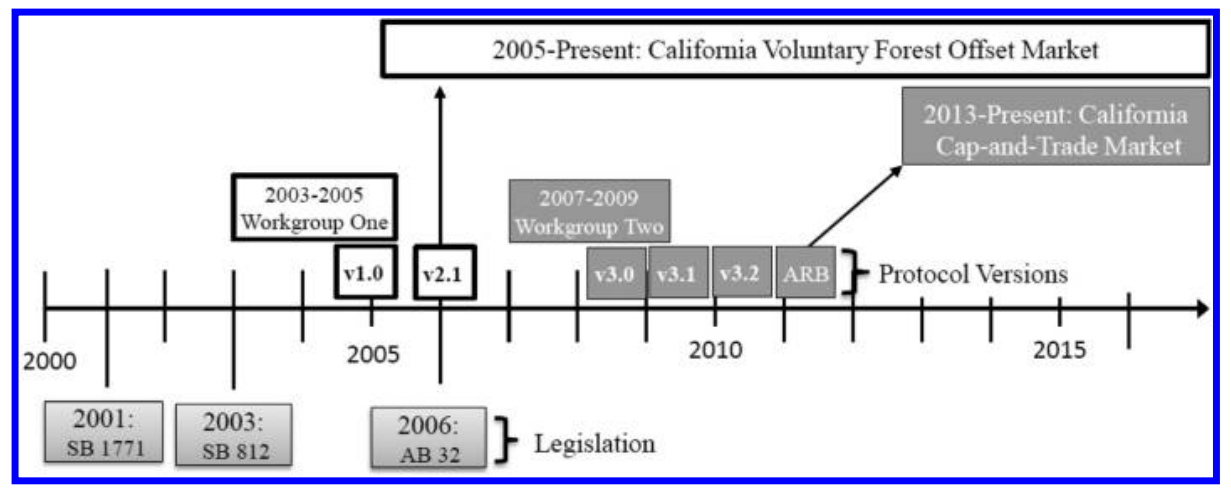

Figure 1

Protocol Development Timeline

Acronyms: SB, Senate Bill; AB, Assembly Bill; ARB, Air Resources Board.

We conclude by looking globally, considering the relevance of California's IFM protocol development for ecosystem markets worldwide.

\section{Analytical Approach}

\section{Payment for Ecosystem Services}

Forest landowners' actions provide ecosystem services such as wildlife habitat and diversity, watershed improvement, scenic landscapes, and carbon storage; PES programs like California's IFM protocol encourage management for these benefits by "compensating landowners for the many public goods they [otherwise] provide at little or no cost to consumers. ${ }^{\prime 3}$ Governing bodies have options for influencing landowners' behavior-including direct state regulation, taxation, and state subsidy programs. Yet the last decade has seen a turn toward PES as a favored tool for environmental governance, in part because it is voluntary, incentive-based, and purports to achieve environmental, economic, and social benefits (Gómez-Baggethun et al. 2010). Further, it fits within a neoliberal paradigm, by theoretically allowing free markets to direct economic decisionmaking (Engel et al. 2008). PES was popularized in a sustainable development context in the 1990s; however, climate mitigation is increasingly driving demand for PES markets, including forest-offset programs (Corbera et al. 2010; van Kooten and Sohgen 2007).

Analysis of PES program construction has considered both the benefits and complexities of delegating methodological design to vested-interest stakeholders.

3. Jenkins, Dylan, and Matt Smith. Domestic Forest Carbon Offsets: Is There a Path to Market? The Consultant (Association of Consultant Foresters), January 2013, 25. 
One perspective is that empowering self-interested actors helps create a more usable program with wider engagement (Wunder et al. 2008). However, concern also exists that because PES programs are developed within "particular environmental, economic, social, and political contexts, [they] are subject to the pushand-pull of many stakeholders" (Engel et al. 2008, 668).

Wide variation in forest carbon protocol standards, particularly in fundamental features such as carbon accounting, suggests that the stakeholder influence in program design may stem from policy choices made about how to monetize a new good. Indeed, analyses of alternative forest-offset protocols found sizeable differences in likely project revenue, cost, and ability to participate (Galik et al. 2009, 2012). For instance, project development expenses alone were projected to vary between $\$ 0$ and $\$ 500$ per hectare, based on methodology (Galik et al. 2012). These findings suggest that forest-offset program design is subjective and yet consequential, warranting detailed investigation into how diverse actors influence the design and functioning of PES markets.

\section{Forest Carbon Policy: "A Discursive Minefield"}

Forest sinks have been consistently controversial since they were first negotiated during implementation of the Kyoto Protocol. Boyd et al. (2008) describe the range of divisive arguments concerning environmental integrity, market efficiency, and methodological design options for forest carbon sequestration, comprising what they call the "politics of sinks." Bäckstrand and Lövbrand (2006) pursue a similar theme, using a discursive analytic framework to examine conflicting knowledge claims, asserting that forest offsets are "one of the most disputed ideas in climate governance" (52). In their framework, three metadiscourses intertwine in forest-offset policy rhetoric. Ecological modernization provides a legitimizing discourse which promotes forest offsets as climate mitigation tools with maximum market flexibility and efficiency; green governmentality operationalizes forest sinks with specialized "eco-knowledges" that are necessary to measure, monitor, and manage forest offsets as tradable goods; and civic environmentalism democratizes forest-offset negotiations by empowering nonstate actors, such as NGOs, to safeguard forest carbon program environmental and social integrity. While some important overlap is identified, Bäckstrand and Lövbrand also highlight points of contention between these narratives, which fuel controversy over the use and design of forestoffset programs. For example, they cite tension between the maximum market efficacy promoted by ecological modernization and the environmental safeguards endorsed by civic environmentalism. Their analysis clarifies how forest sink narratives may translate into climate policy, but it focuses exclusively on programs incentivizing forest plantations in tropical countries. We apply their discursive framework in a new context: the creation of managed forest-offset protocols in the US. 


\section{Forest Carbon Revenue in the US}

We also investigate the relationship between protocol design and landowners' potential for market engagement. The development of voluntary forest carbon market opportunities in the US throughout the 2000s generated interest in who might benefit from these new, nontraditional revenue opportunities. The literature especially analyzed nonindustrial private landowners' willingness and ability to participate in emerging forest carbon programs. Barriers to market entry were frequently identified, especially among small-scale and economically marginal landowners, due to up-front costs and rigorous requirements for accounting, monitoring, and permanence (Charnley et al. 2010; Fischer and Charnley 2011; Fletcher et al. 2009; Markowski-Lindsay et al. 2011; Miller et al. 2012; Thompson and Hansen 2012; Wade and Moseley 2011). This pointed toward a "precision versus practicality paradox," suggesting that program technical rigor reduces landowner access (Gosnell et al. 2011).

From this period of US forest carbon market development, California's IFM protocol emerged as the lone regulatory forest-offset program, and many thus consider it the chief forest carbon revenue opportunity open to US landowners. ${ }^{4}$ However, research has shown that the conservativeness, costliness, and prescriptiveness of California's IFM protocol bode poorly for economically marginal landowners (Galik et al. 2009, 2012; Remucal et al. 2013; Russell-Roy et al. 2014). While limited in scope, this literature suggests a lack of fit between the landowners who might benefit most from carbon revenue, such as those at risk of selling their land and fragmenting the landscape because of loss of economic viability, and the feasibility of market entry. Based on indications that California IFM protocol design is shaping market entry, we consider the policy choices that led to its current form.

\section{Research Methods}

We utilized a qualitative research design consisting of in-depth, semistructured interviews, with additional data drawn from a document review of workgroup meeting notes and attendance at forest carbon policy meetings and conferences. Thirty-six individuals participated in the study, including seventeen protocol development workgroup participants (Table 1). This sample does not comprehensively represent all potential stakeholders, but targeted those primarily responsible for shaping IFM protocol design, which was the focus of this case. The interview participants were deliberately selected. Through meeting minutes, we identified all workgroup members, then specifically solicited private landowner representatives as well as forest verification and academic interests, and excluded from the sample those who did not regularly attend meetings and

4. Caldwell et al. 2014; Smith, Matthew. US Carbon Markets: Where Are They Now-and How Did They Get Here? Forestry Source, February 2010, 5. 
Table 1

Participants Categorized by Stakeholder Group

\begin{tabular}{lcl}
\hline Participant Label & $\begin{array}{c}\text { Number of } \\
\text { Participants }\end{array}$ & Participant Breakdown \\
\hline $\begin{array}{l}\text { Protocol development } \\
\text { workgroup (1\&2) members }\end{array}$ & 17 & $\begin{array}{l}\text { Land trust: } \mathrm{N}=5 \\
\text { Timber industry: } \mathrm{N}=5\end{array}$ \\
& & $\begin{array}{l}\text { Science/academia: } \mathrm{N}=4 \\
\text { Other: } \mathrm{N}=3\end{array}$ \\
Stakeholders outside & 19 & Consulting foresters: $\mathrm{N}=6$ \\
the workgroups & & For-profit carbon developers: $\mathrm{N}=4$ \\
& & Environmental NGOs: $\mathrm{N}=7$ \\
& & Other: $\mathrm{N}=2$ \\
\hline
\end{tabular}

public landowner representatives (e.g., US Forest Service). All but one of the solicited informants from the protocol development workgroups granted our interview request. Stakeholders outside the workgroups were selected by reviewing public comments in response to draft protocol versions, and included professional carbon developers, consulting foresters, and environmental NGOs. The interviews took place between fall of 2013 and summer of 2014 and lasted one to two hours each.

We used customized interview schedules with all participants, based on individuals' particular realms of expertise. Some questions were asked of each participant, including items investigating preferred protocol design elements and supportive rationale, such as "Which baseline accounting method did you support and why?" and "What arguments were made for and against potential permanence mechanisms?" However, the interview content was wideranging. All interviews were audio recorded and transcribed verbatim. When possible we excerpt these transcripts, to convey the results in the participants' own words.

In analyzing the transcripts we conducted open and then focused coding, following the methods of Corbin and Strauss (2014). This involved identification, reduction, and categorization of themes. We then delineated descriptive codes according to stakeholder category, in order to investigate how the expectations for protocol design differed by interest group. Finally, we compared these codes to the framework of Bäckstrand and Lövbrand (2006) to conceptualize the relationship between stakeholders and familiar forest sink narratives. The codes grouped clearly by stakeholder category (Table 2). However, categorical overlap and heterogeneity were both common, and these complexities provide important discussion points below. 
Table 2

List of Metadiscourses and Illustrative Codes, Based on Bäckstrand and Lövbrand (2006)

\begin{tabular}{|c|c|c|}
\hline Discourse & Description & Illustrative Codes \\
\hline $\begin{array}{l}\text { Ecological } \\
\text { Modernization }\end{array}$ & $\begin{array}{l}\text { Emphasis on cost } \\
\text { efficiency, market } \\
\text { flexibility }\end{array}$ & $\begin{array}{l}\text { - A case for even-aged management } \\
\text { - Maximum carbon accounting } \\
\text { - Co-benefits as hindrances to } \\
\text { climate benefit } \\
\text { - Emphasis on offset supply } \\
\text { sufficiency } \\
\text { - Offsets as the only way to grow } \\
\text { the economy }\end{array}$ \\
\hline $\begin{array}{l}\text { Green } \\
\text { Governmentality }\end{array}$ & $\begin{array}{l}\text { Emphasis on scientific } \\
\text { precision and } \\
\text { measurability }\end{array}$ & $\begin{array}{l}\text { - Verifiability as a guiding principle } \\
\text { - A need for credibility } \\
\text { - Set-up to be conservative at } \\
\text { every step } \\
\text { - Revisions aim to reduce gaming } \\
\text { potential } \\
\text { - Need for prescriptiveness } \\
\text { - Setting a gold standard } \\
\text { - Objective of real, additional, } \\
\text { quantifiable, verifiable, permanent } \\
\text { management }\end{array}$ \\
\hline $\begin{array}{l}\text { Civic } \\
\text { Environmentalism }\end{array}$ & $\begin{array}{l}\text { Emphasis on forests } \\
\text { as sources of biological } \\
\text { diversity, livelihood } \\
\text { and cultural values }\end{array}$ & $\begin{array}{l}\text { - Importance of co-benefits } \\
\text { - Importance of landowner incentive } \\
\text { - Forest offsets as the greenest offsets } \\
\text { - Like a conservation easement } \\
\text { - Like a management plan } \\
\text { - Reduces deforestation } \\
\text { - Nonextractive revenue }\end{array}$ \\
\hline
\end{tabular}

\section{The Spadework: Creating, Testing, and Promoting a Voluntary Market for Forest Offsets}

California's regulatory IFM protocol emerged from an important period of experimentation and revision that took place in a voluntary market for offset trading (Figure 1). Early advocates broke ground in methodology design by helping articulate the core forest-offset product specifications of "real, additional, quantifiable, verifiable, and permanent," at a time when the definitions 
of these terms were not yet resolved. Besides advancing forest-offset quantification, the efforts of Workgroup One also gained political and public support for forest-based offsets as GHG reduction tools. The success of this voluntary market facilitated the later inclusion of forest-based offsets in California's regulatory cap-and-trade program, by demonstrating that carbon from managed forests could be quantified and sold as legitimate market commodities.

\section{An Effort Instigated and Run by Land Trusts}

The IFM protocol was predominately crafted by nonstate actors; however, the state spurred and helped shape forest-offset trading through legislation. California Senate Bill (SB) 1771 (ch. 1018, Cal. Stat. 2000) was a critical first step. Contextualized by the 1997 Kyoto Protocol, SB 1771 aimed to make California an early actor in a new age of GHG regulation by establishing the California Climate Action Registry (CCAR), a database for industry emitters to voluntarily monitor and report GHG emissions.

San Francisco-based land trust Pacific Forest Trust, which had worked previously on international forest carbon sequestration policies, saw the creation of CCAR as an opportunity to promote forest offsets in California. ${ }^{5}$ Pursuing this goal, they wrote and sponsored a second piece of legislation, SB 812 (ch. 423, Cal. Stat. 2002) clarifying the role of CCAR to include developing a methodology for the production and sale of forest offsets to registry users. This legislation articulated core concepts that had ongoing influence over methodological design. However, many details, including the forest carbon accounting framework, were left open and were delegated to a workgroup, which was convened by the state in 2003 (Figure 1, Workgroup One). Land trusts were the major workgroup participants, with a small number of additional members from the California Department of Forestry and Fire Protection, the forest industry, and a California electric utility that later purchased forest offsets in the voluntary market.

Workgroup One was small, due partly to uncertainty about the demand for offsets and skepticism that carbon projects on managed forests could benefit landowners on a broad scale. Explained one participant: "People didn't think this was real. Companies weren't beating down the door to be part of [protocol development] because they just didn't think this was going to go anywhere" (Interview 2, Land Trust). Despite this, hopes that forest carbon could facilitate forestland conservation fueled land trust involvement. These early advocates promoted carbon offsets as an alternative revenue stream for managed forests,

5. Conservation land trusts are private, nonprofit organizations pursuing land and resource conservation, through conservation easements and fee acquisition. Conservation easements are legal, generally perpetual agreements that transfer land and resource rights from landowners to third parties, such as land trusts or government agencies. 
capable of preventing parcelization and incentivizing sustainable timber management (Best and Wayburn 2001; Wayburn et al. 2000).

The Workgroup One participants borrowed some concepts from existing GHG accounting conventions, but much of their work broke new ground to avoid the failures of earlier programs, which included low utilization and prohibitive transaction costs. One of the primary changes for California was targeting managed forests. This was seen as a significant advance because it made climate goals potentially compatible with other forest management objectives, such as timber harvest. We focus on three components of the early protocol design: baseline, permanence, and "natural forest management."

\section{Baseline: Establishing a Performance Standard}

A baseline is used to demonstrate additionality-that is, greater carbon sequestration than would have occurred in the absence of project development. Previous forest carbon accounting had used baseline scenarios tailored to individual projects' management options, resulting in baselines that were qualitative in nature and difficult to verify, and that relied on landowner-supplied information about the costs and benefits of alternative land management options (World Resources Institute 2006, 23). This approach was viewed as a participation deterrent, due to the time-consuming burdens placed on project developers. Explained one interviewee: "It was like writing a novel every time you did a carbon project. So it was very, very inefficient" (Interview 28, Land Trust). Workgroup One members therefore favored a performance standard baseline: a consistent, quantitative analysis that could be applied across numerous projects, more clearly conveying risk and return to project developers. Explained one interviewee:

You need to make it so that people know going into the project what they are getting into, and they can do feasibility assessments, they can determine ahead of time whether it is going to be worth the effort ... to make actual expensive up-front investments in order to get the project going. (Interview 28, Land Trust)

The forest regulatory context of California made the performance standard baseline possible. Unlike most states, California has a well-established, prescriptive, and measurable set of guidelines articulated in its Forest Practice Rules, pursuant to the 1973 California Forest Practices Act. Workgroup One utilized these rules as a framework for their baseline methodology, allowing project developers to determine the economic potential of forestland within the constraints of familiar regulatory restrictions. By considering what landowners could have harvested, this method rewarded forests up-front for past growth that exceeded what was required by law, a condition that recognized the value of older forests. At a time when alternative forest carbon protocols credited 
landowners for new growth only, ${ }^{6}$ California workgroup members recognized past beneficial stewardship, a strategy supported by land trusts:

You wanted to say, thank you very much for not having liquidated your forest down to the economically optimal levels and legally allowed levels. Thank you. And here is an alternative revenue stream that will enable you to afford to keep doing that in the face of very compelling economics to do otherwise. (Interview 28, Land Trust)

Yet the baseline premised on California's Forest Practice Rules provoked criticism for inflating credits by allowing conservation-minded landowners to assume the maximum harvest allowable by law under their baseline scenarios, without a clear intention to actually harvest at high levels. Nonetheless, this accounting approach was defended by land trusts as a holistic way to consider forests' twin climate benefits of carbon sequestration and storage.

\section{Permanence via Conservation Easements}

In designing permanence protocols, Workgroup One members pushed for a requirement that landowners place conservation easements on project lands as a means of ensuring that carbon sequestration was permanently maintained. Again, stakeholders drew on familiar tools, selecting conservation easements because they were well-established, legal mechanisms with reputations for contractual strength. Importantly, easements were viewed as superior to other possible permanence tools because they created perpetual obligations to maintain forests as forests, and because they allowed ongoing third-party monitoring by easement holders such as land trusts. These factors offered ways of dealing with inherent uncertainties in the lifespan of atmospheric carbon-that is, the question of how long sequestered forest carbon must be stored to wholly offset emitted carbon tons.

\section{Co-Benefits and "Natural Forest Management"}

The obligation to produce co-benefits-ecological improvements beyond carbon sequestration, such as habitat creation on project lands-was a third major element of protocol design, articulated through a set of rules termed "natural forest management." By requiring landowners to manage for a diversity of timber species and mixed-age classes, it sought to prevent "carbon farms" that maximized carbon sequestration at the expense of ecological integrity. This requirement was a key innovation of the early protocol and one that had continued influence over the program as it evolved. However, unlike with the baseline and permanence requirements, uncertainty clouded the natural forest management component. 
As one carbon registry staff member explained: "You can ask a hundred different people what natural forest management means, and you will get a hundred different responses" (Interview 8, Registry Staff).

\section{A Need for Demonstration Projects}

By 2005, Workgroup One had completed an innovative forest protocol, and demonstration projects were needed to provide evidence that the methodology could successfully bring offsets from managed forests to market. A select group of land trusts and conservation landowners accepted the early market uncertainty and developed California's first forest carbon projects on their own lands. Pacific Forest Trust-the prominent architect of SB 812 and Workgroup One contributor-led the experiment by registering the first carbon project on 2,200 acres of forestland under their management.

During this time, a bifurcation began between non-California forest carbon trading schemes-such as the failed Chicago Climate Exchange-and California's market, which started to command higher prices. Signs of a cap-and-trade market on the horizon also drew the attention of a broader scope of potential landowner participants. Larger industrial timberland owners who had thus far been "keeping an eye over the fence," as one stakeholder described it, watched the opportunities opening in California's forest-offset market with greater interest (Interview 2, Land Trust). Yet attention from a widening pool of actors also fueled critiques about the program. Concern surfaced that California's early protocol favored a narrow group of participants, essentially nonprofit land trusts who were willing and able to meet conservation-oriented requirements, with what one interviewee described as: "projects [that] conveniently fit into the protocol" (Interview 3, Land Trust). The limited nature of participation via early demonstration projects therefore set the stage for calls to improve the protocol and to expand its scope of landowner participation.

\section{"Let's Open Things Up": Revising the Original Protocol to Meet the Expectations of Diverse Stakeholders}

The passage of Assembly Bill (AB) 32, the Global Warming Solutions Act of 2006, was a seminal legislative event with implications for forest offsets. This bill bound larger industries in California to mandatory GHG emissions reductions and signaled the likely use of a cap-and-trade market as a primary tool. This suggested the need to revise the early protocol to make it complianceready-for instance, by including more acreage for an expanded market. This presented an opportunity to alter core aspects of the protocol for newly interested stakeholders-including the California forest industry, who took exception to specific aspects of the protocol perceived to preclude their market participation, and carbon verifiers, who sought a baseline revision and increased rigor. 
Under pressure from the new interests, the California Air Resources Board, tasked with implementing $\mathrm{AB} 32$, reconvened a larger and more diverse workgroup to rewrite the protocol (Figure 1, Workgroup Two). Specific instructions to the Workgroup Two participants indicated they should study ways to "expand its use, and consider how it could be used for private landowners, commercial landowners, as well as public landowners, and also consider how it might be used outside of California" (Interview 8, Registry Staff). Thus, a desire to "get more players in the game," as one state agent put it, was central to the founding directive (Interview 14, State Agency).

Convened in 2007, Workgroup Two therefore added voices from the forest industry, employees of state agencies, and carbon verifiers capable of providing technical expertise. The self-interests were wide-ranging as these actors negotiated key elements of the protocol revision, including the baseline, permanence, and natural forest management (Table 2). Following sections review the major debates and their implications for program design and engagement.

\section{Recasting the Baseline: Building Credibility}

Baseline-related debates about additionality and rigor, stemming from the early protocol's crediting of conservation-owned forests for maximum allowable harvest under California law, were especially contentious in Workgroup Two. Verifier stakeholders, in particular, called for a more conservative baseline, yet land trust participants feared this would reduce landowners' incentives to participate, leaving carbon-rich forests as "sitting ducks" for extraction.

Also present was a debate about the value of previously captured carbon in mature forests versus new sequestration in growing timber. Critics, in particular industrial timber stakeholders, claimed that the original baseline underappreciated the carbon sequestration potential of younger forests and proposed broadening incentives to forests of a variety of age classes. Explained one participant:

The debate is, okay here's an old growth Doug-fir forest. The carbon is already captured ... maybe folks who were more interested in gathering and holding old forest structure would argue, well look the carbon that's there is valuable. And [industry] would say: "Well yeah, that's fine ... but give me recognition for the carbon that we're capturing, because we're growing so many young trees." (Interview 12, Extension Agent)

Proponents of baseline revision-who aimed to "bring forests in at a variety of starting points" - also sought ways to make forest carbon sequestration more compatible with management for timber production (Interview 22, NGO).

Reconciliation was reached through a hybrid methodology that rewarded both standing forest conservation and rehabilitation of cutover lands. "Common-practice" guidelines based on nationwide forest biomass data were implemented to address concerns over consistency and stringency. Common practice became the lower limit for baseline modeling, and forests starting above this metric could still earn credit 
for what they might otherwise have harvested, but with the common-practice number as a floor. On the other hand, forests starting below common practice-potentially degraded lands or forests that had been recently harvested-could enter the market at their current maturity level and gradually earn credit for growth after project initiation. This solution also established baseline rules not tied to Californiaspecific forest regulation, facilitating the goal of national program expansion.

\section{A New Permanence Mechanism: Expanding Access}

Permanence also became contested terrain within Workgroup Two amid debate about how to appropriately ensure that sequestered carbon was retained for meaningful lengths of time. Critics called the requirement for conservation easements the "biggest obstacle" under the early protocol and expressed concern that this requirement foreclosed participation among landowners unable or unwilling to enter perpetual agreements. Not only did conservation easements require lengthy negotiations and funding complexities, but their appeal was very specific, limited typically to land trusts and select family forest owners, and rare among the forest industry and tribes.

Some within Workgroup Two asserted that easements might not actually ensure permanence, highlighting their inability to deal with "reversals" - the voluntary or involuntary loss of forest carbon stocks due to wildfire, disease, wind, or over-harvesting. Conservation easements prohibited over-harvest via legal contract, but they lacked insurance plans for dealing with losses in carbon stocks that could still occur. Many Workgroup Two participants advocated for permanence tools that could "make projects whole again" if reversals transpired. Support gathered around a wholly new system that required landowners to set aside portions of earned credits in insurance accounts known as "buffer pools," which could be drawn on in the event of reversals.

Ultimately a majority of Workgroup Two members adopted the viewpoint that conservation easements were not sufficient to mitigate reversals. A 100-year contractual obligation to maintain carbon stocks past the sale of the last credit, along with buffer pools, was selected as a replacement. However, this timeline was still recognized as a potential hurdle for many landowners. As one forester explained: "From a practical point, one hundred years was way too long [for some landowners]. From a business point of view, you go beyond 50 years, it's kind of forever" (Interview 16, Forester). Thus, while a significant boost in accessibility to some, for others the shift from a permanent easement to a hundred-year commitment may have been a difference without a distinction.

\section{"Natural Forest Management" Revisited: Clarifying a Disputed Concept}

Natural forest management, a vague and disputed concept from the early protocol, now needed clearer articulation. For many-including land trust stakeholders as well as environmental advocates who monitored protocol development from 
outside the process-providing these benefits was extremely important. As one environmental activist explained: "If all you are getting is carbon out of your forest [offset] project, then it is just a one-to-one swap between your smokestack and your forest. And it is pretty hard to get too excited about that" (Interview 23, Conservation NGO).

Yet concern existed among forest industry and other forestry professionals that these constraints just "didn't quite make sense" in the context of forest management (Interview 16, Forester). One criticism was that natural forest management requirements impinged on full carbon sequestration benefit. Questioned one forest industry workgroup member: "If I can take a place and plant an exotic species and not cause any other [regulatory] problem by doing that, then why can't I count that carbon?" (Interview 18, Timber Industry). While some emphasized incompatibilities between management-for-carbon and management-for-co-benefits, others argued more simply that these requirements introduced unnecessary complexity into forest-offset criteria. Advised one participant: "In a carbon protocol, let's focus on carbon and how to quantify it as rigorously as possible. Let's not throw in other barriers" (Interview 25, Registry Staff).

However, participants shared a recognition that natural forest management guidelines served a range of political purposes, including production of a "sheen" of co-benefits to help with "political acceptance" of the protocol (Interview 18, Timber Industry). Interviewees indicated awareness that these provisions could increase the perception of forest projects' environmental integrity for offset buyers seeking a strong environmental cachet, which might boost their appeal and monetary value over competing carbon offset options. These were viewed as important considerations, given that forest-based offsets impart risks on buyers that alternative offsets do not, due to the ongoing possibility of reversal.

Even though the benefits of natural forest management were recognized, major debates remained in considering which management practices would be permitted. A central question concerned the inclusion of even-aged management, or "clear-cutting." Though common to industrial timber management, this practice is maligned by many environmental groups, and was generally considered excluded from the original protocol via the requirement that participants manage for a "diversity of age classes." Industrial interests participating in the second workgroup called vocally for its inclusion, arguing: "the protocols aren't going to work [without clear-cutting].... They're going to exclude such a huge huge area of forestland ownership that your offset program's going to not have adequate offsets to be able to go forward" (Interview 21, Timber Industry). Even-aged management practitioners reminded critics that IFM was meant to be integrated with management for timber, of which even-aged management was a legal and common tool.

The ultimate inclusion of even-aged management in the forest-offset protocol appeased timber interests, but it complicated the 2009 nationwide extension of the program. While the California Forest Practice Rules limited clear-cut sizes and mandated that trees grow to a certain age, other regions of 
Table 3

Summary of Major Changes in Protocol Components

\begin{tabular}{lll}
\hline & Early Protocol & Cap-and-Trade Protocol \\
\hline $\begin{array}{l}\text { Baseline to Determine } \\
\text { Additionality }\end{array}$ & $\begin{array}{l}\text { Baseline of maximum } \\
\text { allowable harvest under } \\
\text { California Forest Practice } \\
\text { Rules }\end{array}$ & $\begin{array}{l}\text { - Nationwide standards } \\
\text { or below Common Practice }\end{array}$ \\
Permanence Mechanism & $\begin{array}{l}\text { Conservation easement } \\
\text { required }\end{array}$ & - 100-year commitment \\
Co-benefits via Natural & $\begin{array}{l}\text { Perception that even-aged } \\
\text { management was excluded }\end{array}$ & $\begin{array}{l}\text { - Even-aged management } \\
\text { explicitly included }\end{array}$ \\
\hline
\end{tabular}

the country had few such restrictions. The natural forest management rules were therefore amended to include similar limitations, though these changes posed problems for some non-California landowners by increasing the opportunity costs of IFM program participation. One workgroup member gave the example of the southeastern US pine industry, which harvests trees at a much younger age than is allowed under the natural forest management guidelines, concluding "right, wrong, or indifferent, it eliminates them from being in this protocol" (Interview 18, Timber Industry).

Changes between the early protocol versions and the cap-and-trade protocol are summarized in Table 3.

\section{Discussion}

This article has explored how diverse participants of successive workgroups negotiated key and consequential program design features in the production of an original IFM cap-and-trade carbon protocol, seeking to harness managed forests as tools for atmospheric GHG reduction. The multiyear protocol development process produced definitions of baseline, permanence, and natural forest management that changed over time, reflecting competing expectations from vested-interest actors seeking to create and legitimize a new market good (Figure 1, Table 3). We now return to the questions that guided this research, particularly: What lessons does this offer for stakeholder-engaged PES program design?

\section{PES and the Determination of Winners and Losers via Program Design}

Unsurprisingly, the results show that vested-interest actors lobbied for design elements that increased their access to new carbon-based revenue streams, supporting the assertion of Engel et al. (2008). The early, land-trust-designed protocol favored conservation-minded landowners, and indeed supported project 
development on lands owned and managed by the land trusts themselves. However, the impending cap-and-trade market compelled the state to reconvene a larger workgroup. Here new actors, particularly forest industry stakeholders, negotiated revisions meant to increase their market access, including removal of the conservation easement requirement and inclusion of even-aged management. These revisions were framed by efforts to improve the protocol, based on the lessons learned through field-testing in a voluntary context and from failed carbon markets elsewhere. However, the design decisions also mirrored shifting stakeholder influence, and frequently resulted in policy choices favoring some workgroup members while detracting from the participation potential of others-for example, in debates over whether to reward older versus younger forests in the baseline criteria.

Stakeholders not only asserted particular realms of self-interest, they did so by invoking the logic of familiar discourses, echoing the framework of Bäckstrand and Lövbrand (2006; see our Table 4).

\section{Table 4}

Framework of Discursive Support for the Commodification of Forest Offsets

\begin{tabular}{|c|c|c|}
\hline Discursive Groups & Workgroup Participants & Illustrative Quote \\
\hline $\begin{array}{l}\text { Ecological } \\
\text { Modernization }\end{array}$ & $\begin{array}{l}\text { Timber and carbon } \\
\text { development industries }\end{array}$ & $\begin{array}{l}\text { "So at some point ... [when] } \\
\text { we've squeezed every ounce of } \\
\text { carbon out of the economy, } \\
\text { now how do we increase the } \\
\text { economy? You know, grow, and } \\
\text { not increase atmospheric } \mathrm{CO}_{2} \text { ? } \\
\text { That's where the offset world } \\
\text { comes in." (Interview 18, } \\
\text { Timber Industry) }\end{array}$ \\
\hline $\begin{array}{l}\text { Green } \\
\text { Governmentality }\end{array}$ & Verifiers, science/academia & $\begin{array}{l}\text { "If [the protocol] is not credible, } \\
\text { people will not engage with it.... } \\
\text { It all depends on the integrity } \\
\text { and the technical rigor and } \\
\text { underpinnings of the scheme." } \\
\text { (Interview 19, Verifier) }\end{array}$ \\
\hline $\begin{array}{l}\text { Civil } \\
\text { Environmentalism }\end{array}$ & $\begin{array}{l}\text { Land trusts, } \\
\text { environmental NGOs }\end{array}$ & $\begin{array}{l}\text { "We started promoting } \\
\text { [the idea that] if you're managing } \\
\text { to optimize carbon, you're doing } \\
\text { it in a way that is true to the } \\
\text { ecosystem functionality, that you're } \\
\text { not turning it into a carbon farm." } \\
\text { (Interview 28, Land Trust) }\end{array}$ \\
\hline
\end{tabular}


Clear resemblances exist between ecological modernization, green governmentality, and civic environmentalism and the main lobbying points of the IFM protocol stakeholders. Timber industry representatives frequently expressed the legitimizing claims of ecological modernization, promoting forest offsets as the most efficient and effective way to mitigate climate change and grow the economy. In promoting carbon as an additional revenue stream compatible with timber extraction, which would increase the offset supply, the timber industry mirrored the state's concern for creating sufficient carbon offset projects to satisfy cap-andtrade demand. Verifier and academic stakeholders approximated the green governmentality discourse by operationalizing the methodology, providing the technical expertise to develop a system of accounting meant to produce credits that were quantifiable and verifiable. Through increased baseline conservativeness and prescriptiveness, verifier and academic stakeholders addressed credibility challenges of the voluntary protocol, which are common to forest offsets generally. Finally, land trust stakeholders promoted environmental integrity via the production of co-benefits, in spite of calls to prioritize maximum carbon sequestration, closely resembling the democratizing safeguards of civic environmentalism.

Important overlap existed between stakeholders' discursive positions, echoing the findings of Bäckstrand and Lövbrand (2006). For example, all stakeholder groups emphasized the need for high technological rigor, the purview of green governmentality. Similarly, co-benefits were ultimately accepted for their ability to boost perceptions of offsets' environmental integrity, even among initial opponents-for instance, forest industry stakeholders. We note that overlap was especially pronounced in Workgroup Two, suggesting that these narratives facilitated the regulatory goals of creating sufficient carbon offsets for market demand, building credibility and measurement precision to meet the expectations of a regulatory market, and establishing wider buy-in from some in the environmental community to broaden program support.

Yet the results also show that these perspectives frequently translated to rival policy objectives. Maintenance of environmental restrictions, the purview of land trust stakeholders, was resisted by timber industry representatives, who saw them as barriers to participation and hindrances to offset supply. Conversely, the possibility of opening the program to larger, industrial landowners offered the robust participation potential sought by state agents, but it complicated the task of ensuring the production of co-benefits and brought reactions from environmental advocates outside the protocol negotiation process, who vocally opposed the inclusion of even-aged management. Finally, increasing the conservativeness and rigor of the baseline strengthened the credibility of the program in terms of accuracy and additionality, but reduced project viability among smaller and more economically marginal landowners-the very landowners often targeted for conservation - who traditionally have less access to up-front capital, limited technical capacity, and low inclination to assume restrictive land encumbrances. While more acres could qualify under the cap-and-trade protocol because large industrial ownerships could enter, small-scale nonindustrial landowners were largely 
excluded. Here, we reiterate the precision-versus-practicality paradox articulated by Gosnell et al. (2011). Despite evidence that small-scale landowners could provide significant carbon sequestration potential (Pan et al. 2011), our findings suggest that workgroup members privileged, perhaps necessarily, high market strength and credibility over participation from smaller landowners. Thus, the California IFM protocol development brought together stakeholder groups of necessary expertise and interests, yet also forced a difficult balancing between discrete objectives. We note that these tensions resemble negotiations between multiple interest groups for other environmental commodity programs-for example, forest certification, where necessary trade-offs are made in balancing environmental, social, and economic considerations (Klooster 2010).

This case study has assessed the methodological design preferences of a specific group of stakeholders: those with access to protocol development via workgroup participation, who supported forest carbon commodification. Yet support for forest offsets is not universal. Prior research had directed critical questions at international forest carbon programs, such as the role of offsets in perpetuating exploitative labor relations, power inequities, and ecosystem degradation (Bumpus and Liverman 2008; Corbera and Brown 2010; Lohmann 2009; Sandbrook et al. 2010). Though we have not covered them here, similar critiques surround California's marketization of forest offsets. By selecting the stakeholders for workgroup participation, the state circumscribed whose voices would contribute to protocol design. One result was that the civic environmentalism discourse was only partially represented in IFM protocol development. The state included reform-oriented groups but excluded more radical critics. The excluded actors ranged from those who argued that the creation of the market affirmed existing power structures, to those who saw the commodity itself as illusory. Some critics played very active roles-attending meetings as nonparticipant observers and voicing specific concerns and objectives via public comment-but ultimately had only minor influence on the protocol design. This is a reminder that workgroup participation was not a comprehensive assemblage: it came by invitation, and the selection favored those professionally involved in some aspect of forest carbon development. This reinforces the precept that liberal market environmentalism, considered a hallmark of US climate policy, empowers certain actors and logics while marginalizing others (Liverman 2004). Future research should consider alternative models for increasing engagement with critical discourses in both PES methodological design and implementation.

\section{Conclusion: Looking Globally}

California established a methodological precedent by creating a regulatory IFM protocol, yet it is not unique in harnessing forests as sinks for GHG reduction. Programs monetizing forest carbon exist globally-both as compliance instruments for emissions trading systems and vehicles for sustainable development, including the Clean Development Mechanism (CDM) and Reduced Emissions 
from Deforestation and Forest Degradation (REDD+). Recent evidence from a World Bank carbon pricing survey found 18 emissions trading systems currently operating across thirty-one countries, with at least thirteen more under consideration (World Bank 2014). This suggests opportunities for policy-makers globally to draw lessons from California's IFM protocol development, in their own considerations of whether and how to commodify forest carbon sequestration.

Specific design elements of California's IFM protocol were frequently tailored to the forest inventory data sets, regulatory requirements, and management practices of the US-especially the baseline and natural forest management approaches. Thus, they may translate poorly to forests in other geographic contexts, particularly those lacking detailed inventory data. Permanence, too, may need rethinking amid varied tenure arrangements. For example, where state, community, or tribal ownership of forest resources is common, permanence may be more easily defined and monitored than in California, where private ownership necessitates long-term contracts between landowners and state regulators. Alternatively, other aspects of the IFM protocol are more generalizable, including the targeting of managed forests and the employment of performance standard baselines. These features were selected to broaden landowner participation, which was viewed as limited under predecessor programs, such as the CDM. As of November 2015, the enrollment of 5.3 million forested acres across 138 IFM projects indicates that these design features are promoting participation. ${ }^{7}$ Global forest-offset programs might therefore consider the benefits of extending forest carbon methodologies beyond tree planting and avoided deforestation, which have thus far been the convention.

More importantly, this case study sheds light on the political process through which vested-interest actors contested access to new carbon-based revenue streams. We suggest that this clarifies the complex process of PES program development, in which actors make design choices that determine the schemes' functioning and effectiveness. Methodologies for forest-offset programs globally will require design adjustments for particular forest types, regulatory frameworks, land management contexts, and tenure systems; however, policy-makers will nonetheless need to contend with who and what to incentivize while discussing appropriate balance points between broad participation, legitimacy and market reception, and environmental integrity, in resemblance to IFM protocol development stakeholders.

\section{References}

Bäckstrand, Karin, and Eva Lövbrand. 2006. Planting Trees to Mitigate Climate Change: Contested Discourses of Ecological Modernization, Green Governmentality and Civic Environmentalism. Global Environmental Politics 6 (1): 50-75.

Best, Constance, and Laurie A. Wayburn. 2001. America's Private Forests: Status and Stewardship. Washington, DC: Island Press.

7. Data from Climate Action Reserve and the American Carbon Registry. 
Boyd, Emily, Esteve Corbera, and Manuel Estrada. 2008. UNFCCC negotiations (preKyoto to COP-9): What the Process Says About the Politics of CDM-sinks. International Environmental Aoreements: Politics, Law and Economics 8: 95-112.

Bumpus, Adam G., and Diana M. Liverman. 2008. Accumulation by Decarbonization and the Governance of Carbon Offsets. Economic Geography 84 (2): 127-155.

Caldwell, Benjamin T., Kyle A. Holland, Zach Barbane, and Melanie Jonas. 2014. AB 32-A Compliance Carbon Market for US Forests, an Opportunity for Foresters. Lournal of Forestry 112 (1): 60-61.

Charnley, Susan, David Diaz, and Hannah Gosnell. 2010. Mitigating Climate Change through Small-Scale Forestry in the USA: Opportunities and Challenges. SmallScale Forestry 9 (4): 445-462.

Corbera, Esteve, Carmen González Soberanis, and Katrina Brown. 2009. Institutional Dimensions of Payments for Ecosystem Services: An Analysis of Mexico's Carbon Forestry Programme. Ecological Economics 68 (3): 743-761.

Corbin, Juliet, and Anselm Strauss. 2014. Basics of Qualitative Research: Techniques and Procedures for Developing Grounded Theory. New York: Sage.

Engel, Stefanie, Stefano Pagiola, and Sven Wunder. 2008. Designing Payments for Environmental Services in Theory and Practice: An Overview of the Issues. Ecological Economics 65 (4): 663-674.

Fischer, A. Paige, and Susan Charnley. 2011. Social and Cultural Influences on Management for Carbon Sequestration on US Family Forestlands: A Literature Synthesis. International Journal of Forestry Research 2010: 960912. doi:10.1155/2010/960912.

Fletcher, Lena S., David Kittredge, and Thomas Stevens. 2009. Forest Landowners' Willingness to Sell Carbon Credits: A Pilot Study. Northern Journal of Applied Forestry 26 (1): 35-37.

Galik, Christopher S., David M. Cooley, and Justin S. Baker. 2012. Analysis of the Production and Transaction Costs of Forest Carbon Offset Projects in the USA. Iournal of Environmental Management 112: 128-136.

Galik, Christopher S., Megan L. Mobley, and Daniel deB Richter. 2009. A Virtual "Field Test" of Forest Management Carbon Offset Protocols: The Influence of Accounting. Mitigation and Adaptation Strategies for Global Change 14 (7): 677-690.

Gómez-Baggethun, Erik, Rudolf De Groot, Pedro L. Lomas, and Carlos Montes. 2010. The History of Ecosystem Services in Economic Theory and Practice: From Early Notions to Markets and Payment Schemes. Ecological Economics 69 (6): 1209-1218.

Gosnell, Hannah, Nicole Robinson-Maness, and Susan Charnley. 2011. Engaging Ranchers in Market-Based Approaches to Climate Change Mitigation: Opportunities, Challenges, and Policy Implications. Rangelands 33 (5): 20-24.

Klooster, Dan. 2010. Standardizing Sustainable Development? The Forest Stewardship Council's Plantation Policy Review Process as Neoliberal Environmental Governance. Geoforum 41: 117-129.

Liverman, Diana. 2004. Who Governs, at What Scale and at What Price? Geography, Environmental Governance, and the Commodification of Nature. Annals of the Association of American Geographers 94(4): 734-738.

Lohmann, Larry. 2009. Neoliberalism and the Calculable World: The Rise of Carbon Trading. In Upsetting the Offset: The Political Economy of Carbon Markets, edited by Steffen Boehm and Siddhartha Dobhi, 25-40. London: Mayfly Books.

Markowski-Lindsay, Marla, Thomas Stevens, David B. Kittredge, Brett J. Butler, Paul Catanzaro, and Brenton J. Dickinson. 2011. Barriers to Massachusetts Forest Landowner Participation in Carbon Markets. Ecological Economics 71: 180-190. 
Miller, Kristell A., Stephanie A. Snyder, and Michael A. Kilgore. 2012. An Assessment of Forest Landowner Interest in Selling Forest Carbon Credits in the Lake States, USA. Forest Policv and Economics 25: 113-122.

Pan, Yude, Richard A. Birdsey, Jingyun Fang, Richard Houghton, Pekka E. Kauppi, Werner A. Kurz, Oliver L. Phillips, Anatoly Shvidenko, Simon L. Lewis, Josep G. Canadell, Philippe Ciais, Robert B. Jackson, Stephen W. Pacala, A. David McGuire, Shilong Piao, Aapo Rautiainen, Stephen Sitch, and Daniel Hayes. 2011. A Large and Persistent Carbon Sink in the World's Forests. Science 333 (6045): 988-993.

Remucal, Jonathan M., Jason McGee, Mathew Fehrenbacher, Constance Best, and Robert Mitchell. 2013. Application of the Climate Action Reserve's Forest Project Protocol to a Longleaf Pine Forest under Restoration Management. Lournal of Forestry 111 (1): 59-66.

Russell-Roy, Emily T., William S. Keeton, Jennifer A. Pontius, and Charles D. Kerchner. 2014. Rehabilitation Forestry and Carbon Market Access on High-Graded Northern Hardwood Forests. Canadian Journal of Forest Research 44 (6): 614-627.

Sandbrook, Chris, Fred Nelson, William M. Adams, and Arun Agrawal. 2010. Carbon, Forests and the REDD Paradox. Oryx 44 (3): 330-334. doi:10.1017/S0030605310000475.

Thomas, Sebastian, Paul Dargusch, Steve Harrison, and John Herbohn. 2010. Why Are There So Few Afforestation and Reforestation Clean Development Mechanism Projects? Land Use Policy 27 (3): 880-887.

Thompson, Derek W., and Eric N. Hansen. 2012. Factors Affecting the Attitudes of Nonindustrial Private Forest Landowners Regarding Carbon Sequestration and Trading. Journal of Forestry 110 (3): 129-137.

van Kooten, G. Cornelis, and Brent Sohngen. 2007. Economics of Forest Ecosystem Carbon Sinks: A Review. Working Paper 2007-02, Resource Economics and Policy Analysis (REPA) Research Group, Department of Economics, University of Victoria, BC.

Wade, David, and Cassandra Moseley. 2011. Foresters' Perceptions of Family Forest Owner Willingness to Participate in Forest Carbon Markets. Northern Journal of Applied Forestry 28 (4): 199-203.

Wayburn, L. A., J. F. Franklin, J. C. Gordon, C. S. Binkley, D. J. Mladenoff, and N. L. Christensen, Jr. 2000. Forest Carbon in the United States: Opportunities \& Options for Private Lands. San Francisco: Pacific Forest Trust.

World Bank. 2014. State and Trends of Carbon Pricing 2014. Washington, DC: World Bank. World Resources Institute. 2006. The Greenhouse Gas Protocol: The Land Use, Land Use Change, and Forestry Guidance for GHG Project Accounting. Available at www.ghgprotocol.org/ standards/project-protocol, accessed January 10, 2015.

Wunder, Sven, Stefanie Engel, and Stefano Pagiola. 2008. Taking Stock: A Comparative Analysis of Payments for Environmental Services Programs in Developed and Developing Countries. Ecological Economics 65 (4): 834-852. 